\title{
Relationship between psychological distress and physical symptoms of functional dyspepsia with the mediating role of pain-related mental imagery, visceral sensitivity, pain catastrophizing and pain self-efficacy
}

\author{
Sepehr Mohajerani ${ }^{1}$, Ali Issazadegan ${ }^{2}$, Esmaiel Soleimani $^{3}$, Ziba Khoram $^{4}$ \\ 1-Ph.D Student, Department of Psychology, Urmia University, Urmia, Iran. \\ 2- Professor, Department of Psychology, Urmia University, Urmia, Iran (Corresponding Author). \\ E-mail: Aliessazadegan10@yahoo.com \\ 3- Associate Professor, Department of Psychology, Urmia University, Urmia, Iran. \\ 4- Gastroenterology Sub-specialist, Department of Internal Medicine, Shahid Beheshti University of Medical \\ Sciences, Tehran, Iran.
}

Received: 02/10/2021 Accepted: 22/12/2021

\begin{abstract}
Introduction: Functional dyspepsia is a group of gastrointestinal disorders in which the psychological symptoms play a significant role in their incidence.

Aim: The aim of this study is determination of the relationship between psychological distress and physical symptoms of functional dyspepsia with the mediating role of pain-related mental imagery, visceral sensitivity, pain catastrophizing and pain self-efficacy.

Method: The present study is conducted using the descriptive cross-sectional method. The statistical population includes all patients with functional dyspepsia referred to gastrointestinal clinics of Isfahan in 2021-2022. The statistical population consists of 363 people who are selected by the convenience sampling. Instruments include Depression Anxiety Stress Scale, Nepin Dyspepsia Index, Chronic Pain Mental Image Questionnaire, Visceral Sensitivity Index, Pain Catastrophizing Scale and Chronic Pain Self-Efficacy Questionnaire. Software such as smart-PLS, SPSS-23 and descriptive indices and structural equations are used for data analysis.
\end{abstract}

Results: Results showed that the direct path of psychological distress (0.329), pain-related mental imagery (0.396) and pain catastrophizing (0.234) to physical symptoms were significant. Also, the indirect paths from psychological distress to physical symptoms through the mediating pain-related mental imagery, pain catastrophizing, and self-efficacy on pain-related mental imagery and visceral sensitivity on pain-related mental imagery with values of $0.052,0.231$, 0.058 and 0.246 respectively had significant relations.

Conclusion: The results show that the pain-related mental imagery, visceral sensitivity, pain catastrophizing and pain self-efficacy play a mediating role between the psychological distress and physical symptoms of functional dyspepsia. It is suggested that these factors are included in patients treatment plans to reduce recurrence, exacerbation of symptoms and burden of the disease.

Keywords: Dyspepsia, Psychological distress, Catastrophization, Self-efficacy

How to cite this article: Mohajerani S, Issazadegan A, Soleimani E, Khoram Z. Relationship between psychological distress and physical symptoms of functional dyspepsia with the mediating role of pain-related mental imagery, visceral sensitivity, pain catastrophizing and pain selfefficacy. Shenakht Journal of Psychology and Psychiatry. 2022; 8 (6): 98-113 .URL: http://shenakht.muk.ac.ir/article-1-1279-en.pdf

Copyright $\odot 2018$ the Author (s). Published by Kurdistan University of Medical Sciences. This is an open access article distributed under the terms of the Creative Commons Attribution-Non Commercial License 4.0 (CCBY-NC), where it is permissible to download, share, remix, transform, and buildup the work provided it is properly cited. The work cannot be used commercially without permission from the journal. 


\title{
رابطهى يريشانى روانشناختى و علائم جسمانى سوء هاضمه عملكر دى با نقش ميانجى ذهنى مرتبط با درد، حساسيت احشايى، فاجعه آفرينى درد و خودكار آمدى درد
}

\author{
سبهر مهاجرانى '، على عيسى زادكان'، اسماعيل سليمانى '، زيبا خرم \\ ا.دانشجوى د كترى، گروه روانشناسى، دانشخاه اروميه، اروميه، ايران. \\ ب. استاد، گروه روانشناسى، دانشخاه اروميه، اروميه، ايران (مولف مسئول). ايميل: Aliessazadegan10@yahoo.com \\ r. دانشيار، گروه روانشناسى، دانشگاه اروميه، اروميه، ايران.

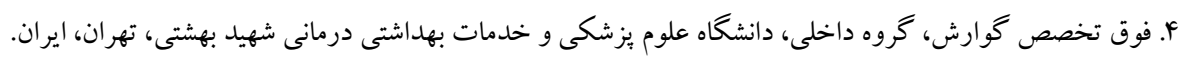

مقلمه: سوء هاضمه عملكردى جزء گروهى از اختلالات كوارشى است كه علائم روانى در بروز آن نقش قابل توجهى دارد. هدف: يزٔوهش حاضر با هدف تعين رابطهى بريشانى روانشناختى و علائم جسمانى سوء هاضمه عملكردى با نقش ميانجى گرى تصاوير ذهنى مرتبط با درد، حساسيت احشايى، فاجعه آفرينى درد و خود كار آمدى درد انجام شد.

روش: ئزوهش حاضر به روش توصيفى- مقطعى انجام شد. جامعه آمارى شامل تمامى افراد مبتلا به سوء هاضمه عملكردى

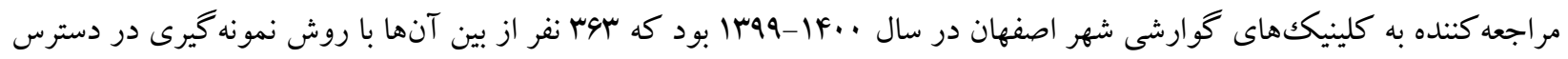
انتخاب شدند. ابزارهاى بزٔوهش شامل مقياس افردگى، اضطراب و استرس، شاخص سوء هاضمه نيين، يرسشنامه تصاوير ذهنى درد مزمن، شاخص حساسيت احشايى، مقياس فاجعه آفرينى درد و برسشنامه خود كار آمدى درد مزمن بود. از نرمافزارهاى Smart-PLS، نسخه سז، شاخص هاى توصيفى و معادلات ساختارى براى تحليل دادهها استفاده شد.

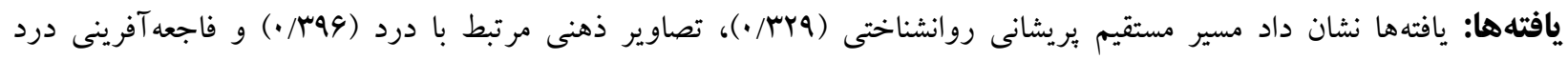

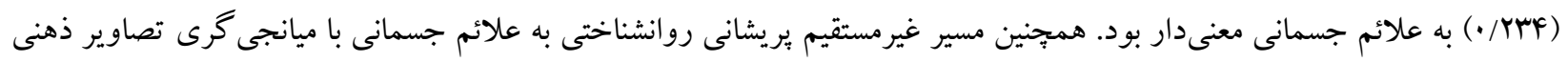

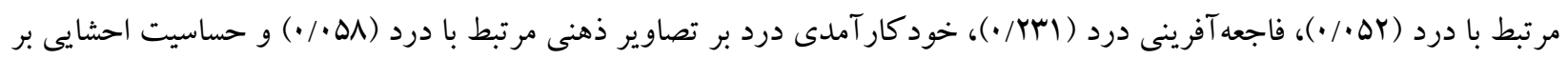
تصاوير ذهنى مرتبط با درد (YF9 / •) معنىدار بود. نتيجه گيرى: نتايج نشان داد تصاوير ذهنى مرتبط با درد، حساسيت احشايى، فاجعه آفينى درد و خود كار آمدى درد نقش واسطهاى ميان يريشانى روانشناختى و علائم جسمانى سوء هاضمه عملكردى دارد. بيشنهاد مىشود اين عوامل در برنامههاى درمانى بيماران كنجانده شود تا به تبع آن از عود مجدد بيمارى، تشديد علائم و بار بيمارى كاسته شود. كليدوازهها: سوء هاضمه، يريشانى روانشناختى، فاجعه آفرينى، خود كار آمدى 
از غذا خوردن، سيرى زودرس و سوزش و درد آزار دهنده ناحيه ايى كاستر " (سر دل) شناخته شده كه در نبود شواهد ساختارى و ارگانيك در آندوسكويى با فوقانى آنى باشد. علائم تكميلى شامل نفخ و ورم شكم، تهوع و استفراغ و آروغ زدن است (موشيرى و تالى، اب.Y.Y). نتايج يزوهشى حاكى از آن است كه قبل از شكل گيرى اين علائم يريشانى روانشناختى در مقدار قابل توجهى از

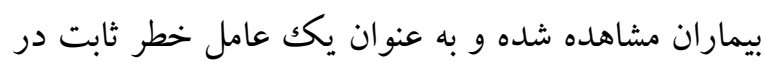
باتوزنز سوء هاضمه عمل مي كند (كلسكى، جونز، واكر، كلى هالتمن "rا و همكاران، (Y.Y. (Y).

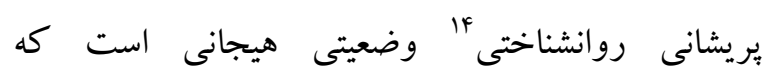
دربر گيرندهى ناراحتى، ناميدى، افسردگى و اضطراب است. اين وضعيت يكك تجربهى بيوسته و غالباً ناهشيار از احساس نگرانى، تحريك يذيرى و فشار روانى فراهم مىسازد كه رفتارهاى آشكار و نآشكار فرد را تحت تأثير قرار مىدهد (وزيرى و لطفى كاشانى، بهاب). طبق تعريفى ديخر بريشانى روانشناختى حالات ذ ذهنى ناخوشايند افسردگى و اضطراب است كه هر دو علائم هيجانى و فيزيولوزيكى را دارد (تيزدل و آنتال فا 19 19.ب). مشخص شده است بيدا كردن مسيرى نوين براى تسكين بريشانى روانشناختى و درد بيماران در گرو توجه كردن به تعامل بييجيده بين تصاوير ذهنى و ابعاد تجربه درد نهفته

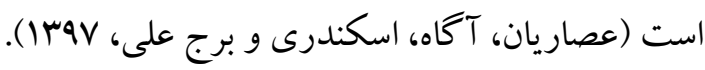
تصاوير ذهنى مرتبط با دردو'، تصاويرى قابل دسترس و و داراى كيفيتى بويا هستند كه بينش قدرتمندى در مورد تجربه ذهنى درد بيماران ارائه مىدهند. اغلب اين

\footnotetext{
${ }^{11}$ - Epigastrium

12. Endoscopy

${ }^{13}$ - Koloski, Jones, Walker, Keely \& Holtmann

${ }^{14}$ - Psychological distress

${ }^{15}$ - Teasdale \& Antal

${ }^{16}$ - Pain-related mental imagery
}

مقله

اختلالات كوارشى كاركردى' شايعترين اختلالات دستخاه گوارش هستند كه حدود هاء از مراجعين به مراكز تخصصى كوارش را شامل مىشود (ساهان،

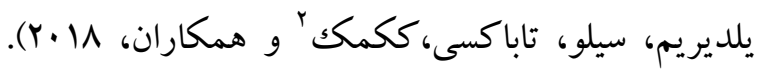
يكى از انواع رايج اين اختلالات سوء هاضمه عملكردى سيّا

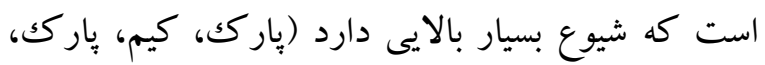

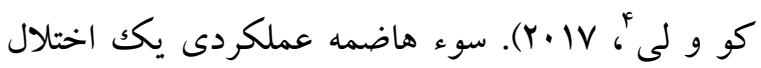

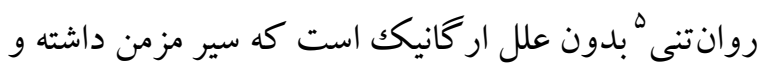
موجب كاهش سلامت و افت كيفيت زندگى بيماران مىشود (باطبى، مسجدى آرامى، جعفى، صادقى، صابرى و همكاران، ·r.r.r؛ محمودى، مداحى، بور شريفى

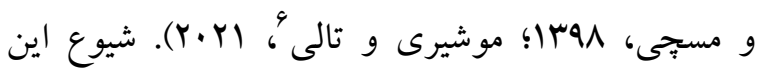
بيمارى در جمعيتهاى مختلف متفاوت بوده و از ه تا

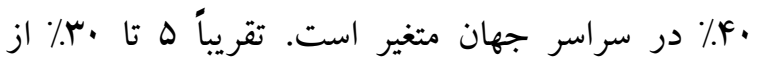

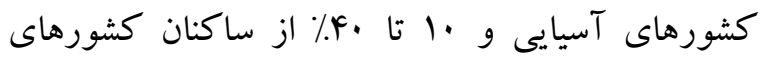

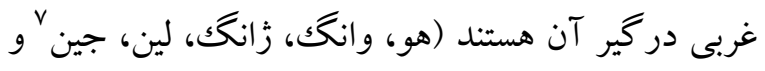

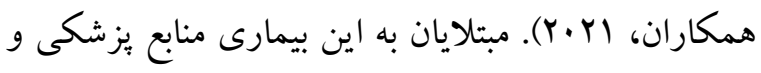
هزينههاى مراقبتى - بهداشتى زيادى صرف بيمارى خود مى كنند و دادههاى جِند جمعيت اروبايى و آمريكاى شمالى نشان داده است حدود .r\% بيماران به علت علائم شديد روزهاى خود را خارج از محل كار و مدرسه

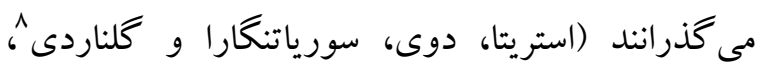

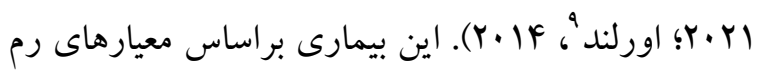

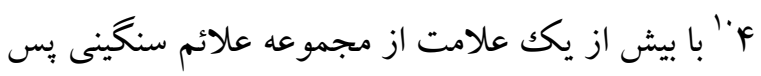

\footnotetext{
1. Functional gastrointestinal disorders

2 - Sahan, Yildirim, Soylu, Tabakci \& Cakmak

3 - Functional Dyspepsia

4- Park, Kim, Park, Ko \& Lee

5- Psychosomatic disorder

6. Moshiree \& Talley

7. $\mathrm{Hu}$

8 - Esterita, Dewi, Suryatenggara \& Glenardi

9 - Overland

${ }^{10}$ - Rome IV
} 
روانشناختى، مىتواند منجر به بروز علائم سوء هاضمه عملكردى شود. مطرح شده است شدت گرفتن اين علائم با فاجعه آفرينى بيماران از درد خود ارتباط تنگاتنكى دارد

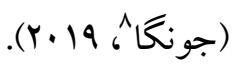

فاجعه آفرينى درد" تمايل به بزر گنمايى در ميزان تحريك

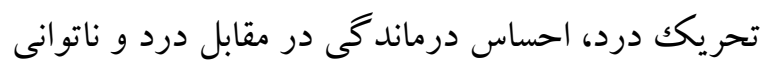
در مهار افكار مربوط به درد در هنگام درد يا انتظار درد است و در شكست مداخلات درمانى نقشى غير قابل انكار دارد (ورتلى، بورگك استالر، وايزراستيور، كافمل '

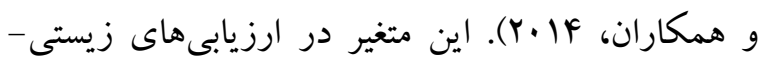
روانى - اجتماعى بيماران مبتلا به اختلالات كوارشى عملكردى عامل مهمى بوده و ارتباط آن با كسترش

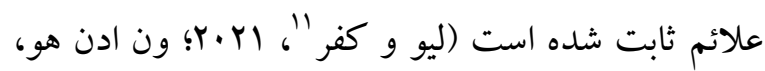
كراول و دراسمن، هلبرت، كفر و همكاران"، 19 19. (Y). آخرين متغير ميانجى اين يثزوهش كه براساس مفاهيم نظرى و شواهد تجربى با علائم سوء هاضمه عملكردى

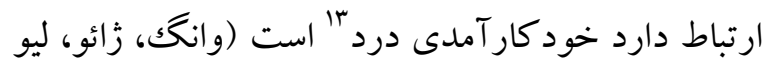

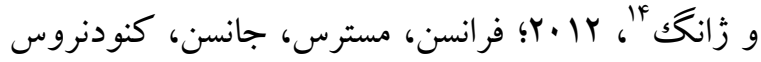

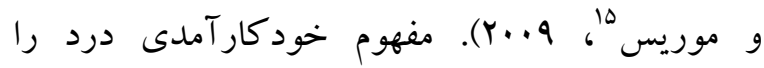

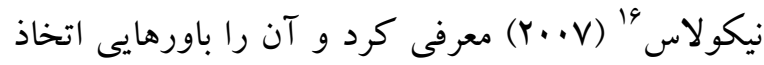
شده در افراد مبتلا به درد مزمن تعريف كرد كه مىتو انند منجر به فعاليتهاى خاص حتى در زمان تجربه درد شوند و به طور بالقوه بر توانايى براى دستيابى به اهدافى كه در اثر بيمارى مانع مىشوند، تأثير مى گذارد (كاركولا،

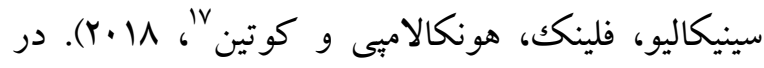

\footnotetext{
8 - Junga

9 - Pain catastrophizing

${ }^{10}$ - Wertly, Burgstaller, Weiser, Steurer \& Kofmehl

11. Luo \& Keefer

${ }^{12}$ - Van Oudenhove, Crowell, Drossman, Helpert \& Keefer

${ }^{13}$ - Pain self-efficacy

14- Wang, Zhao, Liu \& Zhang

${ }^{15}$ - Fransen, Mesters, Jansen, Knottnerus \& Muris

${ }^{16}$ - Nicholas

${ }^{17}$ - Karkkola, Sinikallio, Flink, Honkalampi \& Kuittinen
}

تصاوير، درد را به شكل مجازات و حالتى شوم بازنمايى مى كنند. تصاوير ذهنى درد با سو گيرى شناختى مرتبط بوده و درصد قابل توجهى از آنها مربوط به رويدادهاى كذشته و آيندهاى هستند كه با برآوردهاى قابل توجه تهايدهايى مثل از دست دادن شغل، خانو اده، فرصتها و توان مالى همراهاند (كيركهام، اسميت، هاوستين فرانكلين'، هاب(Y). در همين رابطه كاروترز، ميلر،

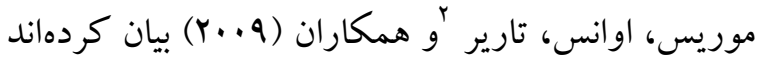
نمرههاى بالا در علائم غير كولونى بيماران مبتلا به

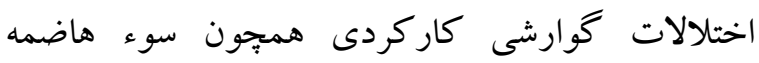
عملكردى با تصاوير ذهنى درد مرتبط هستند. بديدهاى مهم كه مىتواند علت بسيارى از علائم غير قابل توضيح دستخاه كوارش را آشكار كند حساسيت احشايى باست (لين، ساروسيك، فرستر، دامجانو، هو بو و

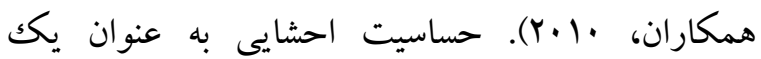
نابهنجارى شامل ادراكات و احساسات فزون يافته از محركهاى احشايى تجربه شده است كه معمولاً در بيماران داراى اختلالات كوارشى عملكردى ديده مىشود و در حال حاضر نقش بزرگى را در علت درد مزمن احشايى غير قابل توجيه بازى مى كند (ماير و

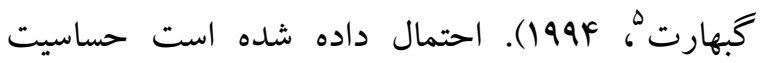
احشايى با عوامل روانشناختى مثل اضطراب، افسردگى و استرس مرتبط باشد (نوتن، اسجوشيم، پياتل، جِيتكارا و

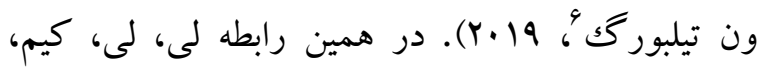

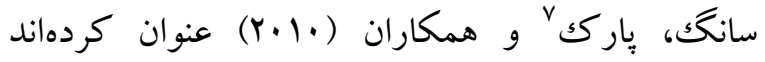
حساسيت احشايى تحت اثر خذارى عوامل استرسزاى

\footnotetext{
1. Kirkham, Smith \& Havsteen-Franklin

${ }^{2}$ - Carruthers, Miller, Morris, Evans, Tarrier \& Whorwell

3 - Visceral sensitivity

${ }^{4}$ - Lin, Sarosiek, Forster, Damjanov \& Hou

5 - Mayer \& Gebhart

${ }^{6}$ - Newton, Schosheim, Patel, Chitkara \& van Tilburg

7- Lee, Lee, Kim, Sung \& Park
} 
ابزارهاى يُزوهش مىشود. براى اطمينان سوب نفر (MFF) زن و 119 مرد) براساس تشخيص فوق تخصص گُوارش

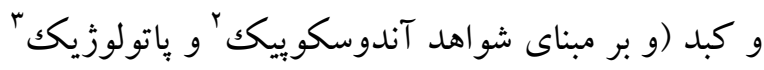

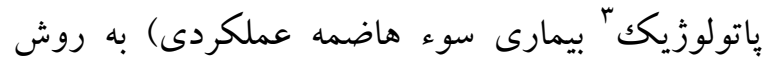
نمونه كيرى در دسترس انتخاب شدند. پِ از از ذكر توضيحات لازم درباره هدف بثزوهش به شركت كنند كان

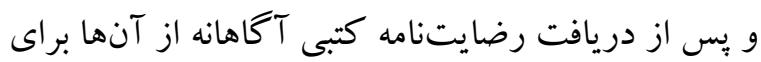
شر كت در مطالعه، در كنار محرمانه ماندن اطلاعاتشان، از

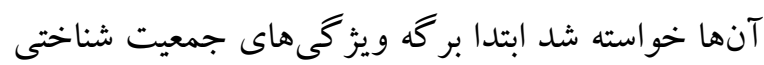
را تكميل نمايند و پيس از بررسى، آزمودنىهايى كه شرايط لازم براى ورود به مطالعه را داشتند، انتخاب شدند. معيارهاى ورود به بثزوهش عبارت بود از: دارا بودن حداقل سواد براى دركك سؤالات برسشنامه، واجد علائم سوء هاضمه عملكردى باشند و هنوز به مرحله بهبودى نرسيده باشند و ملاككهاى خروج عبارت بودند

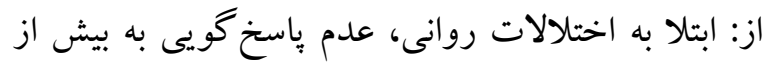
هاء سؤالات برسشنامههاى مورد استفاده، عدم تمايل و دقت كافى حين باسخدهى به برسشنامه ها. در اين يزوهش

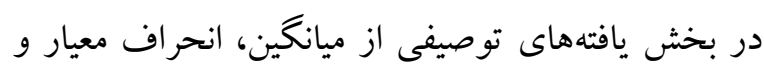

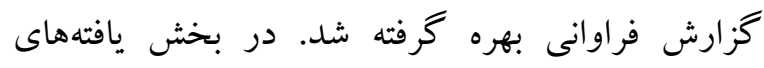
استنباطى ابتدا براى بررسى نرمال بودن توزيع دادهها

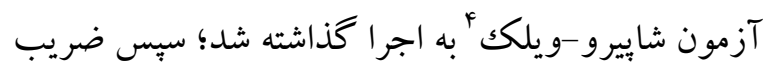
ضريب همبستكى بين متغيرها محاسبه شد و در كام آخر براى ارزيابى برازش مدل و آزمون فرضيهها مدليابى معادلات ساختارى به روش حداقل مربعات جزئى هبه كار

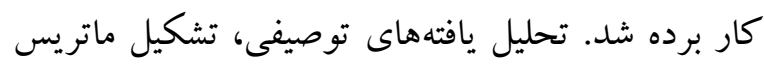
همبستكى بين متغيرها و بررسى توزيع نرمال بودن متغيرها

2. Endoscopic

${ }^{3}$ - Pathologic

4- Shapiro-Wilk

5 - Partial Least Squares
همين رابطه تحقيقات نشان داده خودكارآمدى رابطه

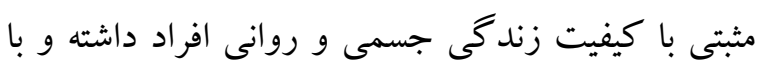
بريشانى روانشناختى ارتباطى معكوس دارد (موشر،

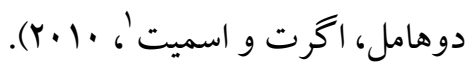
بررسى ارتباط علائم سوء هاضمه عملكردى با متغيرهاى متعدد هدف كوشش هاى بثزوهشى متفاوتى بوده است كه به يافته هاى ارزشمندى منتهى شدهاند؛ اما در اين زمينه هنوز يرسشهاى فراوانى وجود دارند كه ضرورت تدابير جديد يزوهشى و در نظر گرفتن متغيرهاى ديخر رابه ونه ميان مى آورند. يثوهش حاضر با اتخاذ اين نكته و به ميان آوردن مؤلفههايى كه ورود بعضى از آنها به اين قلمرو تقريباً جديد است، از زاويه ديخرى به اين مسئله برداخته است؛ بنابراين با توجه به مطالب مطرح شده و اهميت موضوع، هدف اصلى اين مطالعه تعيين رابطهى يريشانى روانشناختى و علائم جسمانى سوء هاضمه عملكردى با نقش ميانجى گرى تصاوير ذهنى مرتبط با درد، حساسيت احشايى، فاجعه آفرينى درد و خود كار آمدى درد بود. روش يثوهش حاضر از نوع بزوهشهاى بنيادى- كاربردى و روش آن توصيفى- مقطعى است. جامعهُ آمارى اين يثزوهش شامل تمامى افراد مبتلا به سوء هاضمه عملكردى مراجعه كننده به كلينيككهاى گوارشى شهر اصفهان در سال . . F-1F99 بودند. با توجه به اينكه در اين مطالعه، متغير بيشبين پيريشانى روانشناختى شامل دو مؤلفه، متغيرهاى ميانجى مجموعاً شامل يازده مؤلفه و متغير ملاكك علائم جسمانى شامل سه مؤلفه بود، مطابق با ملاكك مكك كالم، براون و سو گووارا (1999) حجم نمونه به ازاى هر متغير به تعداد ها تا ·r برابر مؤلفهاى

\footnotetext{
1- Mosher, DuHamel, Egert \& Smith
} 


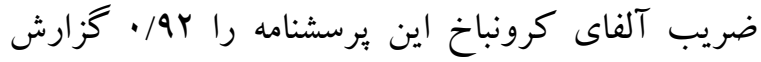
كردهاند.

مقياس افسردكى، اضطراب، استرس" (DASS-21): اين مقياس توسط لاويبوند و لاويبونده در سال 1990 منتشر شد و فرم كوتاه شده نمونه اصلى Fr آيتمى است. كاربرد مهم آن اندازه گيرى نشانهاى اصلى افسردگى، اضطراب و استرس است. هر يكك از سه خرده مقياس شامل هفت سؤال است و در طيف ليكرت جهار درجهاى از اصلاً=. تا زياد= F نمره گذارى مى شوند. همبستخى بين زيرمقياس افسردگى، اضطراب و استرس اين مقياس با آزمون

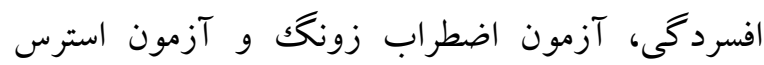

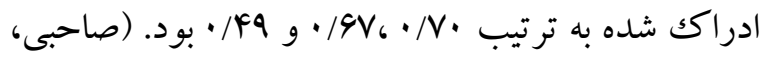
اصغرى و سالارى، (أوNAF). شيخ، منصور جوزان و امينى (1M99) ضريب آلفاى كرونباخ را براى اين برسشنامه r/Ar/ • گزارش كردند. اين ضريب در تحقيقات بيبى، لين،

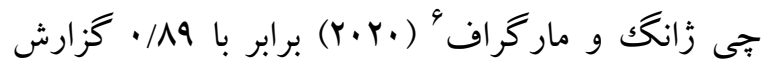

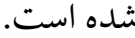

يرسشنامه تصاوير ذهنى درد مزمن ' (SF-MQ-2): اين "يرسشنامه توسط دوركين، تورك، رويكى، هاردينگك،

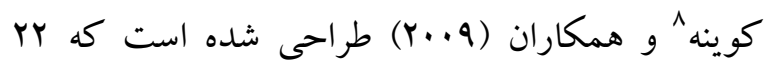
سؤال دارد و تصاوير ذهنى درد مزمن را در م خرده

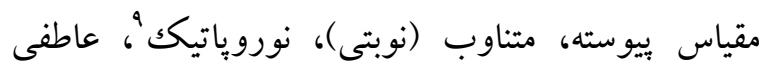

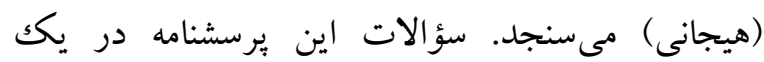
ييوستار |l درجهاى از هيج=" تا شديدترين حالت ممكن= · ا نمره كذارى مىشوند. ضريب آلفاى كرونباخ نسخه فارسى شده اين برسشنامه 91 • كز ارش شده است

4- Depression, Anxiety and Stress Scale-21

5 - Lovibond \& Lovibond

6- Bibi, Chi-zahng \& Margraf

7- Short Form-McGill Pain Questionnaire-2

${ }^{8}$ - Dworkin, Turk, Revicki, Harding \& Goyne

${ }^{9}$ - Neuropathic
بهوسيله نرمافزار SPSS نسخه بr و تحليل يافته هاى مدل معادلات ساختارى با استفاده از نرمافزار smart-PLS

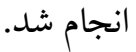

ابزار فرم اطلاعات جمعيت شناختى: مشخصات جمعيت

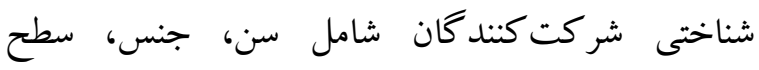
تحصيلات، وضعيت تأهل، وضعيت اشتغال و وضعيت اقتصادى از طريق فرم اطلاعات جمعيت شناختى جمع آورى گرديد. شاخص سوء هاضمه نيين' (NDI): شاخص سوء هاضمه

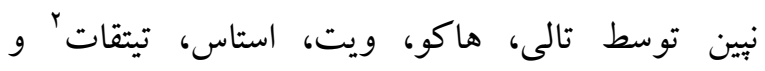
همكاران در سال 1999 طراحى شده است. اين شاخص شامل دو بخش نمره علائم و كيفيت زندگى است كه بخش اول علائم 9 كانه درد در قسمت فوقانى شكم، ناراحتى معده، تهوع، استفراغ، سوزش سر دل، نفخ، احساس سيرى زودرس، احساس سنگينى بعد از خوردن غذا و آروغ زدن بيش از حد را ارزيابى مى كند. نمره اين 9 علامت بيمارى، از محاسبه (افراوانى+شدت + برزحمت / ير دردسر بودن) به دست مى آيد. عبارتهاى اين شاخص در طيف ليكرت ينج درجهاى از هيج = تا خيلى شديد=ه نمره گذارى مىشوند. ضريب پايايى نسخه فارسى شده

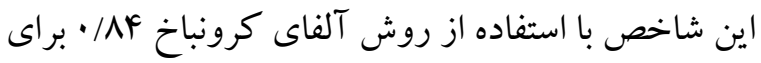
بخش علائم و روايى آن با استفاده از ضريب همبستكى

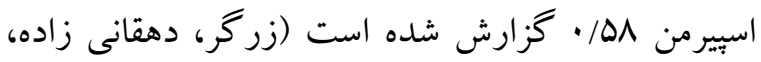
مهرابى زاده هنرمند و كدخدايى، (qبا)). همجينين انكورونزيزا، دوسابجامبو، اورهارت و بنسنَّ (Y.19)

\footnotetext{
1- Nepean dyspepsia index

${ }^{2}$ - Talley, Haque, Wyeth, Stace \& Tytqat

${ }^{3}$ - Nkurunziza, Dusabejambo, Everhart \& Bensen
} 
ضريب آلفاى كرونباخ كل در اين يزوهش سواه

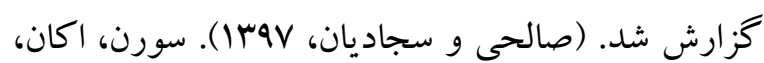
كو كباكان، كايا، اركوركماز' و همكاران (Y.|F) ضريب آلفاى كرونباخ اين مقياس را • / • عنوان كردند. "برسشنامه خودكارآملدى درد مزمن " (CPSEQ): اين

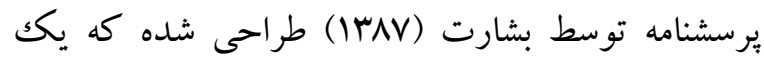
ابزار ها سؤالى است و خودكارآمدى اختصاصى درد

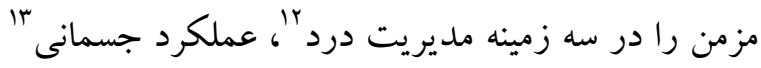

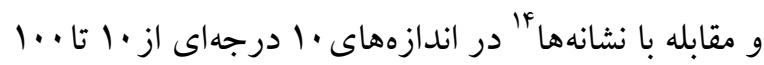
مىسنجد. حداقل و حداكثر نمره بيمار در كل برسشنامه به ترتيب ل10 و ...10 و در هر يكك از خرده مقياسهاى

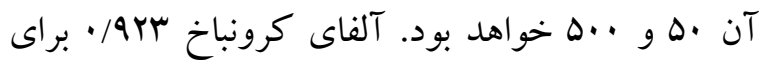
اين برسشنامه در نمونهاى از بيماران مبتلا به درد مزمن متشكل از 109 نفر (NV) نفر زن و 99 نفر مرد) بدست آمده است (بشارت كوجى، دهقانى، فراهانى و مؤمن

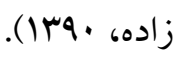

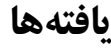

يافتهاى جمعيت شناختى نشان داد كه بوس نفر مورد مطالعه، 9V/T درصد زن و M/N درصد مرد بودند. درصد مجرد، 9/ه/ه درصد متأهل، ب درصد مطلقه و 9 / درصد همسرشان فوت شده بود. 94/F درصد شاغل و

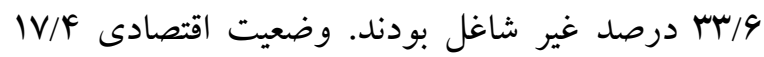
درصد خوب، 91/9 درصد متوسط و ff أ درصد ضعيف بود. از نظر تحصيلات ه/9 درصد سيكل، \&/4 درصد دييلم، 19/9 درصد فوق دييلم، س/ א درصد ليسانس، 1×1 درصد فوق ليسانس و ب درصد دكترى داشتند.

${ }^{10}$ - Suren, Okan, Gokbakan, Kaya \& Erkorkmaz

${ }^{11}$ - Chronic Pain Self Efficacy Questionnaire

${ }^{12}$ - Pain Management

13. Physical Function

${ }^{14}$ - Coping with Symptoms
(كجويى، ابراهيم زاده، عرفانى سيار، صالحى، سليمى و

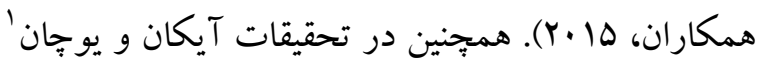

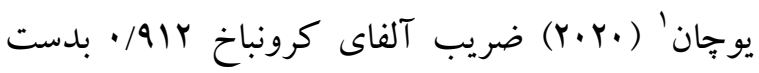
آمد.

شاخص حساسيت احشايح' (VSI): اين شاخص توسط لاباس، ناليبوف، برمان، سوينوبو، وياناخ و همكاران طراحى شده است كه ها ماده دارد و كاربرد آن (Y...F) اندازه گيرى نشانگان ويزه حساسيت احشايى است. عبارتهاى اين شاخص در طيف ليكرت 9 درجهاى از خيلى مخالفم= · تا خيلى مو افقم=ه نمره كذارى مى شوند. نسخه فارسى شده اين برسشنامه از روايى و بيايايى مناسبى برخوردار است و براى اجرا در نمونه ايرانى مناسب است. همجنين اين برسشنامه ضريب پيايايى بالايى دارد (آلفاى كرونباخ= سو/•) (يورتو كلى، حاجى عليز اده و سماوى،

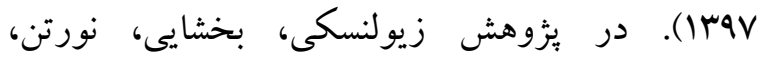

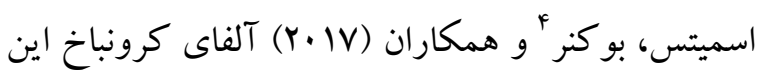

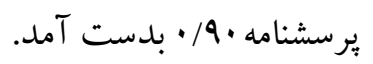

مقياس فاجعهآفرينس درده (PCS): ساليوان، بيشاب و و بيويكك (1990) جهت ارزيابى فاجعه آفرينى درد بيماران بيماران اين مقياس سا آيتمى را طراحى كردهاند. اين

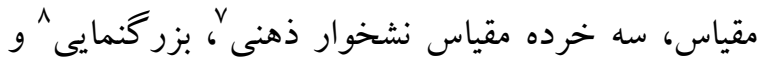

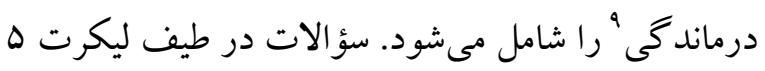
ه درجهاى از اصلاً=. تا هميشه= F نمره كذارى مىشوند. اين مقياس توسط سجاديان، نشاط دوست، مولوى و باقريان سرا رودى (| (1/) به فارسى ترجمه و اجرا شده و

\footnotetext{
1- Aykan \& Uçan

2. Visceral Sensitivity Index

3 - Labus, Naliboff, Berman, Suyenobu \& Vianna

4- Zvolensky, Norton, Smits \& Buckner

5 - Pain Catastrophizing Scale

6. Sullivan, Bishop \& Pivik

7- Rumination

8 - Magnification

9 - Helplessness
} 
ميانگين و انحراف معيار سن افراد به ترتيب برابر بودن توزيع نمرات آزمودنىها بهوسيله آزمون شابيرو r/

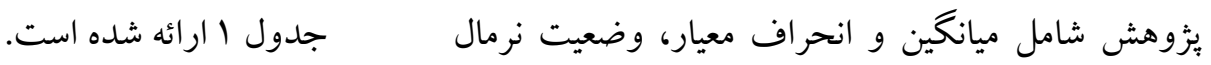

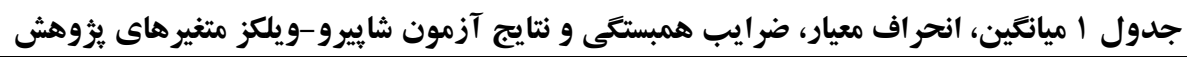

\begin{tabular}{|c|c|c|c|c|c|c|c|c|c|}
\hline & & ل اسيير من & 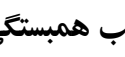 & ضر & & Z & انحر اف & ميانگين & متغير ها \\
\hline \multirow[t]{6}{*}{9} & $\Delta$ & p & $r$ & $r$ & 1 & شايِرو ويلكى & & & \\
\hline & & & & & 1 & $\cdot / 994^{\text {******\% }}$ & $r I / T r$ & $9 \Lambda / 9 V$ & ا-يريشانى روانشناختى \\
\hline & & & & 1 & $\cdot / 9 \cdot 9^{* *}$ & $\cdot / 99 \mathrm{~V}^{* * * *}$ & $\mid F / F V$ & $\mathrm{Fr} / \mathrm{A}$. & r-حساسيت احشايى \\
\hline & & & 1 & $-\cdot / 911^{* *}$ & $-\cdot / \wedge \Delta F^{* *}$ & 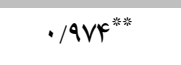 & $r q \Lambda / \cdot V$ & $994 / 01$ & r-خود كار آمدى درد \\
\hline & & 1 & $-\cdot / \wedge 9 F^{* *}$ & $\cdot / 949^{* *}$ & $\cdot / \Lambda V^{* *}$ & . $/ 99 .^{* * * * *}$ & $41 / 99$ & $\mid r r / 9 V$ & ץ-تصاوير ذهنى مرتبط \\
\hline & 1 & $\cdot / 94 \Delta^{* *}$ & $-\cdot / 9 \cdot \wedge^{* *}$ & $\cdot / 9 F^{* *}$ & $\cdot / \Lambda V^{* *}$ & $\cdot / 9 \vee 9^{* * * *}$ & $Q / \mu r$ & rQ/r & ه-فاجعه آفرينى درد \\
\hline 1 & $\cdot|\wedge 9|^{* *}$ & $\cdot / 199^{* *}$ & $-\cdot / \wedge \Delta r^{* *}$ & $\cdot / \wedge 9 f^{* *}$ & $\cdot / M \Lambda F^{* *}$ & $\cdot / 94 r^{* * *}$ & 19/V9 & $9 \mathrm{~V} / \cdot \Delta$ & 9-علائم جسمانى \\
\hline
\end{tabular}

همانطور كه جدول ا نشان مىدهد تمام ضرايب كفت فرض نرمال بودن متغيرهاى يُزوهش در نمونه

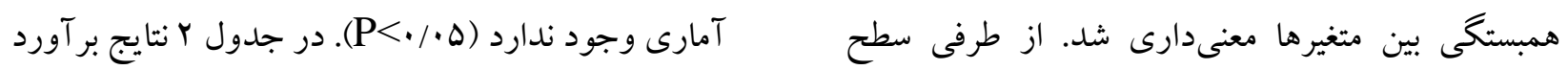

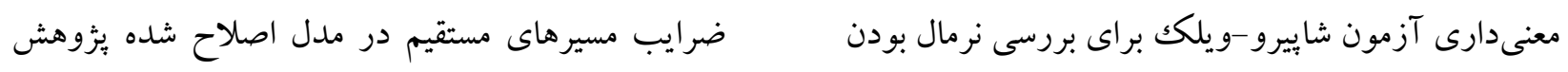

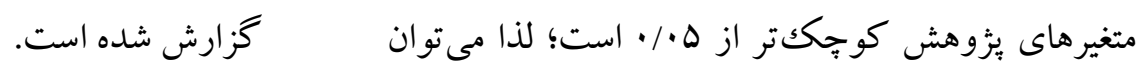

\begin{tabular}{|c|c|c|c|}
\hline سطح معنىدارى & 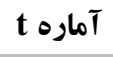 & ضريب مسير & 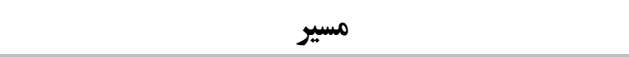 \\
\hline$\cdot \cdots$ & $\Delta \Delta / q \mu q$ & $\cdot / 9 r^{* * * *}$ & يريشانى روانشناختى -> حساسيت احشايى \\
\hline.$/$ & $\mathrm{rq} / \mathrm{gqF}$ & $-\cdot / \Lambda F Q^{* * * *}$ & يريشانى روانشناختى -> خود كار آمدى درد \\
\hline$\cdot \cdots \Delta$ & $r / \Lambda \cdot r$ & $\cdot / 1 r \cdot{ }^{* * * *}$ & يريشانى روانشناختى -> تصاوير ذهنى مرتبط با درد \\
\hline$\cdot \cdots$ & $\Delta V / I \mu \Lambda$ & 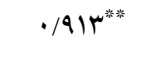 & يريشانى روانشناختى -> فاجعه آفرينى درد \\
\hline 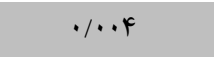 & $r / M 9$ & $\cdot / R Q^{* * * *}$ & يريشانى روانشناختى -> علائم جسمانى \\
\hline.$\cdots$ & $F / \wedge \Delta G$ & $\cdot / \Gamma 94^{* * * *}$ & تصاوير ذهنى مرتبط با درد -> علائم جسمانى \\
\hline$\cdot / \cdot \mathrm{rV}$ & $r / Y I I$ & $\cdot / M r F^{* * * *}$ & فاجعه آفرينى درد -> علائم جسمانى \\
\hline$\%$ & $1 \cdot 11 \cdot 9$ & $\cdot 19 \vee 9^{* * * *}$ & حساسيت احشايى -> تصاوير ذهنى مرتبط با درد \\
\hline$\cdot \cdots$ & $r / \Delta \wedge \Delta$ & $-\cdot / 1 V^{* * * *}$ & خود كار آمدى درد -> تصاوير ذهنى مرتبط با درد \\
\hline
\end{tabular}

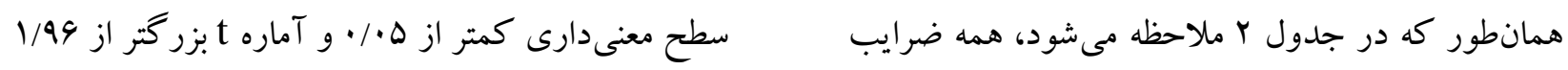
مسيرهاى مستقيم مدل اصلاح شده ئزوهش با توجه به معنى 
جدول Г بر آورد ضرايب مسير هاى غير مستقيم مدل اصلاح شده يزوهش

\begin{tabular}{|c|c|c|c|}
\hline معنى سطح & t & ضريب & مسير \\
\hline$\cdot \%$ Y & r/YOF &.$/ \cdot \Delta r^{* * *}$ & يريشانى روانشناختى -> تصاوير ذهنى مرتبط با درد ->>علائم جسمانى \\
\hline.$/ \cdot \mathrm{IV}$ & r/raq & $-.1 .99^{* * *}$ & خود كار آمدى درد -> تصاوير ذهنى مرتبط با درد -> علائم جسمانى \\
\hline$\cdot / \cdots$ & $\Delta / I V I$ & $\cdot / 49 \Lambda^{* *}$ & حساسيت احشايى -> تصاوير ذهنى مرتبط با درد -> علائم جسمانى \\
\hline 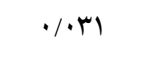 & r/lar & $\cdot / r \mid r^{* * *}$ & بريشانى روانشناختى -> فاجعه آفرينى درد -> علائم جسمانى \\
\hline$\cdot \cdots$ & $1 \cdot /$ rYr & $\cdot / 9 Y Y^{* * *}$ & بريشانى روانشناختى ->> حساسيت احشايى -> تصاوير ذهنى مرتبط با درد \\
\hline$\cdot \cdots$ & $r / \Delta ৭ 9$ & $\cdot / / F V^{* * *}$ & يريشانى روانشناختى ->>خود كار آمدى درد ->> تصاوير ذهنى مرتبط با درد \\
\hline$\%$ & $\Delta / \cdot 1 f$ & $\cdot / r F q^{* * *}$ & يريشانى روانشناختى ->> حساسيت احشايى -> تصاوير ذهنى مرتبط با درد ->>علائم جسمانى \\
\hline.$/ \cdot 1 \mathrm{~V}$ & r/rqV & $\cdot / \cdot \Delta \Lambda^{* * *}$ & يريشانى روانشناختى ->> خود كار آمدى درد -> تصاوير ذهنى مرتبط با درد -> علائم جسمانى \\
\hline
\end{tabular}

خود كار آمدى درد در ارتباط بين يريشانى روانشناختى و

علائم جسمانى است. جدول ل، ضريب آلفاى كرونباخ، وايايى تركيبى و ميانگين واريانس استخراج شده را نشان مىدهد. در ادامه ميزان بايايى و روايى مدل اندازه گيرى ئزوهش ارائه مى گردد.
همانطور كه در جدول r ملاحظه مىشود، آماره t براى همه ضرايب مسيرهاى غيرمستقيم بزر گتر از 199 ا و سطح معنى تمامى ضرايب غيرمستقيم در مدل اصلاح شده است و حاكى از معنىدارى نقش ميانجى تصاوير ذهنى مرتبط با درد، حساسيت احشايى، فاجعه آفرينى درد و و

\begin{tabular}{|c|c|c|c|}
\hline \multicolumn{4}{|c|}{ جدول ^ يايايى و روايى مدل اندازه كيرى يزوهش } \\
\hline ميانكين واريانس استخراج شده & هايايى تركيبى & آلفاى كرونباخ & عناصر \\
\hline$\cdot / A V V$ &.$/ 999$ & $\cdot / 90 r$ & تصاوير ذهنى مرتبط با درد \\
\hline $1 / \cdot \cdot$ & $1 / \cdot$ & $1 / \cdot$ & حساسيت احشايى \\
\hline.$/ 994$ & $\cdot / 9 M$ & $\cdot / 911$ & خود كار آمدى درد \\
\hline$\cdot / A F \Lambda$ & $\cdot / 944$ &.$/ 911$ & علائم جسمانى \\
\hline$\cdot / 190$ & $\cdot / 90$. & $\cdot / 9 Y Y$ & فاجعه آفرينى درد \\
\hline - var & $\cdot / 919$ & $\cdot / \wedge 91$ & 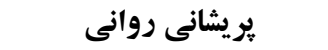 \\
\hline $\mathrm{AVE}>\cdot / \Delta$ & $\mathrm{CR}>\cdot / \mathrm{V}$ & Alpha $>\cdot / \mathrm{V}$ & حد قابل قبول \\
\hline
\end{tabular}

اندازهيرى بُزوهش مورد تائيد است. همجنين ميانگين مطابق با جدول f ضريب آلفاى كرونباخ و يايايى تركيبى واريانس استخراج شده همه متغيرها از هاء بيشتر است

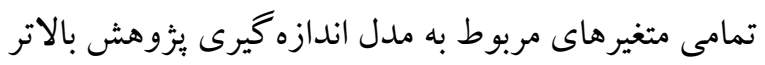
از V/ • است؛ بنابراين مىتوان كفت كه پيايايى مدل 
جسمانى داشت بلكه اثر گذارى يريشانى روانشناختى، حساسيت احشايى و خودكارآمدى درد را بر علائم جسمانى ميانجى گرى كرد كه با نتايج مطالعات جست و الى (199V) مبنى بر ارتباط تصاوير ذهنى مرتبط با درد با مريا

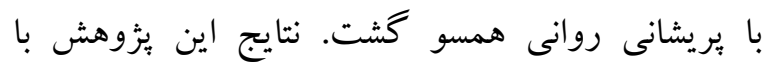

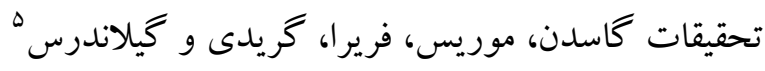
(Y.|F) ذهنى با ناخوشايندى درد و ايجاد علائم بيمارى ارتباط

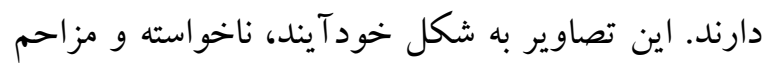
به ذهن بيمار نفوذ مى كنند و اغلب بريشان كننده هستند

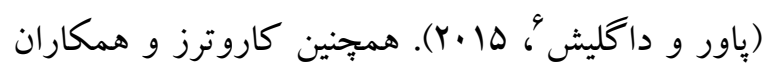

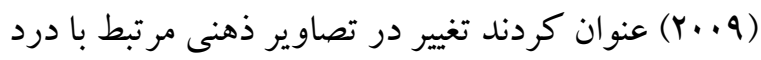
منجر به بهبود علائم بيمارى مىشود. در توجيه اين

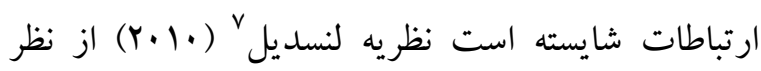
كذرانده شود كه معتقد بود اين تصاوير موجب تغيير جهت به سمت خُلق منفى مى شود. اين خلق و هيجانات منفى همجيون اضطر اب، خشم و غم به صورت معنى دارى افزايش يافته و هيجانات مثبت كاهش مىيابند و روند جسمانىسازى و كسترش نشانها در اين تسلسل معيوب سرعت مى گيرد. توجيه دقيقتر اين مسئله در مطالعات

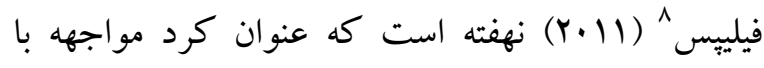
تصاوير مرتبط با درد، ارزيابىهاى شناختى را تغيير مىدهد و افراد بعد از اينكه تصاوير ذهنى خودآيند دردشان را فراخوانى كردند، ذهنيت آنها منفىتر مىشود. اين تصاوير باعث بيشبينى رويدادهاى ناخوشايند در آينده و خودارزيابىهاى منفى شده و

$$
\text { كسترش علائم جسمانى را شدت مى بخشد. }
$$

4- Just \& Alloy

5 - Gosden, Morris, Ferreira, Grady \& Gillanders

6 - Power \& Dalgleish

7 - Lonsdale

${ }^{8}$ - Philips
كه خود دال بر تائيد روايى همخراى مدل اندازهگيرى

$$
\text { يثزوهش است. }
$$

يزوهش حاضر با هدف بررسى نقش ميانجى تصاوير ذهنى مرتبط با درد، حساسيت احشايى، فاجعه آفرينى درد و خود كار آمدى درد در رابطه با بريشانى روانشناختى و علائم جسمانى سوء هاضمه عملكردى انجام شد. نتيجه تحليل نشان داد در كنار مسير معنىدار پيريشانى روانشناختى با هر يكك از متغيرهاى ميانجى كه در ادامه بحث مىشود، رابطه اين متغير با علائم جسمانى تائيد

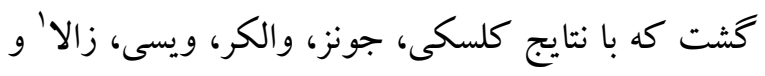

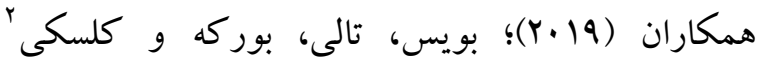

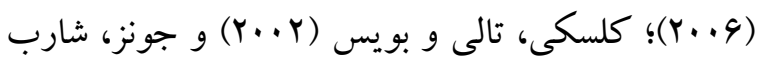

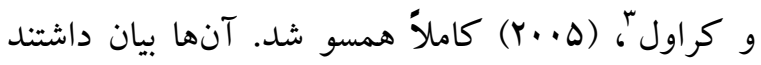
يريشانى روانشناختى با علائم سوء هاضمه عملكردى ارتباطى قابل توجه دارد. در توجيه اين ارتباط مى توان كفت درد، سوزش و نفخ به عنوان علائم جسمانى آزار دهنده اين بيمارى عموماً مبتلايان را منزوى كرده و از بر عان

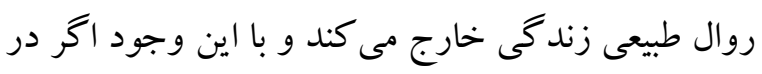
اجتماع حضور يابند به دليل فشار روانى ناشى از بيمارى

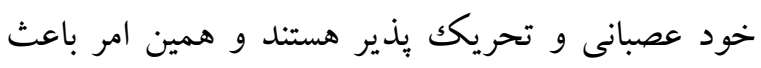
بالا رفتن اضطراب آنها شده و جرخهاى را به وجود مى آورد كه بين اضطراب و افسردگى و بروز علائم در برد

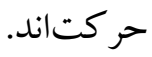

در ميان متغيرهاى ميانجى يزوهش حاضر تصاوير ذهنى مرتبط با درد نقشى كليدى رادر ييشبينى علائم جسمانى بيماران ايفا كرد؛ جرا كه نه تنها اثر مستقيمى بر علائم

\footnotetext{
1- Veysey \& Zala

${ }^{2}$ - Boyce, Talley \& Burke

${ }^{3}$ - Jones, Sharp \& Crowell
} 
به ميان آورد كه بيان داشتند استرس، اضطراب و افسردگى منجر به آزاد سازى فاكتور آزاد كننده

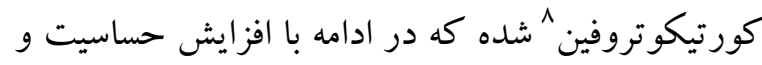
درد احشايى همراه مىشود. اين فزون يافتكىها سرانجام منجر به توليد تصاوير ذهنى مرتبط با درد شده و علائم جسمانى متعددى را ايجاد مى كند. آخرين متغير ميانجى اين بزوهش فاجعهآفرينى درد بود كه آزمون ضرايب مسير ارتباط آن با علائم جسمانى و و يريشانى روانشناختى را نشان داد. در همين رابطه نتايج

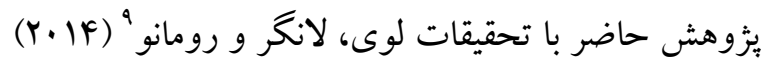

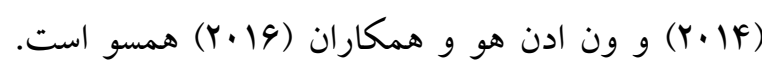
آنها بيان كردند كاهش فاجعه آفرينى از مهم ترين عوامل در كاهش علائم سوء هاضمه عملكردى است. در توجيه اين ارتباط مىتوان گفت بزرخنمايى و نشخوار ذهنى، ارزيابى از علائم بيمارى را بىنهايت تهديد كننده مى كند

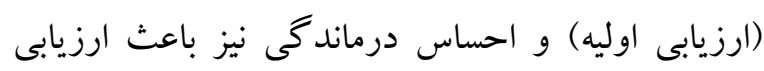
ناتوانى براى مقابله در برابر علائم مىشود (ارزيابى ثانويه)؛ بنابراين از اين طريق فاجعها آفرينى، تجربه درد و

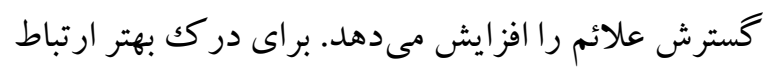

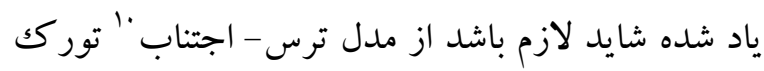

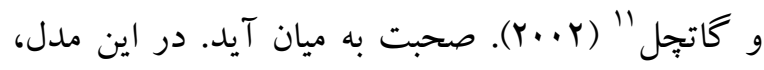
فاجعه آفرينى درد نقشى محورى ايفا مى كند. فرد با فاجعه آفرينى درد وارد جرخهاى معيوب متشكل از ترس مرتبط با درد، گوشبهزنگى، عواطف منفى و اجتناب مىشود. اجتناب نيز باعث كاهش فعاليتهاى جسمانى و اجتماعى، نابسامانىهاى روانشناختى و احساس ناتوانى و

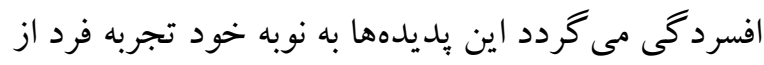

${ }^{8}$ - Corticotropin-releasing factor

9- Levy, Langer \& Romano

${ }^{10}$ - Corticotropin-Releasing Factor

${ }^{11}$ - Turk \& Gatchel
خود كار آمدى درد از ديخر متغيرهاى ميانجى يثوهش حاضر بود كه مسير ارتباط آن با بريشانى روانشناختى معنى

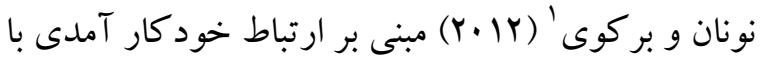
استرس و علائم افسردگى به عنوان ابعادى از بريشانى روانشناختى در يكك راستا قرار كرفت. همهِين ضرايب مسير نشان كه تأثير اين متغير بر علائم جسمانى از طريق تصاوير ذهنى مرتبط با درد بود. در تبيين اين نتايج همسو

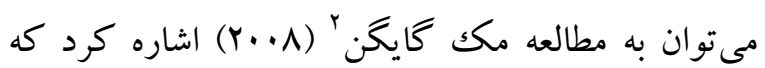
معتقد بود خود كار آمدى درد باعث كاهش عو اطف منفى و بر انخيختخى فيزيولوزيكك همراه آن مىشود؛ و از اين طريق نقش كاهش دهندهاى در شدت درد دارد؛ زيرا عواطف منفى از طريق افزايش فعاليت سيستم سمياتيكک

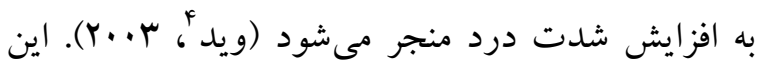
عو اطف منفى در ادامه منجر به توليد تصاوير ذهنى مرتبط با درد شده و گسترش علائم را شتاب مىبخشد. همانطور كه از يافتها بر مى آيد مسير حساسيت احشايى به بريشانى روانشناختى و علائم جسمانى معنى دار شد كه

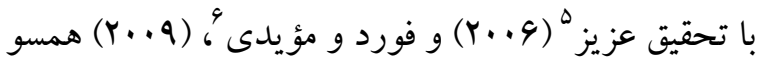
همسو كشت. يثوهش اول بيانكر اين موضوع بود كه اضطراب كمتر با افت حساسيت احشايى در ارتباط است و يزوهش دوم حساسيت احشايى را به عنوان يك أك مكانيسم تأثير گذار در شكل گيرى علائم جسمانى سوء هاضمه عملكردى مطرح كرد. در توجيه اثر گذارى حساسيت احشايى بر علائم جسمانى از طريق تصاوير

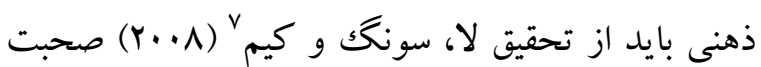

\footnotetext{
1- Amtmann, Bamer, Cook, Askew, Noonan \& Brockway

${ }^{2}$ - MC Guigen

${ }^{3}$ - Sympathetic

${ }^{4}$ - Wade

5 - Aziz

${ }^{6}$ - Ford \& Moayyedi

7. La, Sung \& Kim
} 
مقاله حاضر بركرفته از رساله دوره دكترى رشته

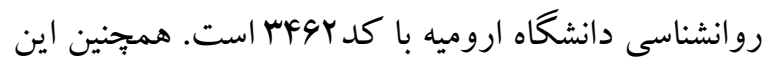
مطالعه توسط كميتهى اخلاق بزوهش هاى زيست بز شكى

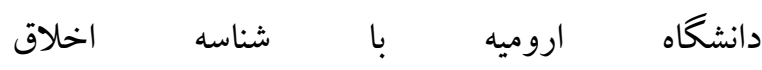
IR.URMIA.REC.1399.004 تائيد شده است. بدينوسيله از تمامى افرادى كه در اين ئوهش شركت كردند و با صبر و حوصله به سؤالات باسخ دادند كمال تشكر را داريم.

\section{References}

Amtmann D, Bamer AM, Cook KF, Askew RL, Noonan VK, Brockway JA. (2012). University of Washington self-efficacy scale: a new self-efficacy scale for people with disabilities. Arch Phys Med Rehabil. 93(10), 1757-65.

Asarian HA, Agah M, Eskandari H, Borjali A. (2018). Pain-related automatic mental images and its impact on pain experience. Iranian Joumal of Anesthesiology and Critial Care. 2(2): 49-62. (In Persian)

Aykan SA, Ucan H. (2020). Reliability and Validity of the Turkish Short-Form McGill Pain Questionnaire-2 (TR-SF-MPQ-2) in patients with chronic low back pain. Turk J Phys Med Rehabil. 66(3), 343-350.

Aziz Q. (2006). Visceral hypersensitivity: fact or fiction. Gastroenterology. 131(2), 661-664.

Barzkar M, Pourhoseingholi MA, Habibi M, Moghimi-Dehkordi B, Safaee A, Pourhoseingholi A. (2009). Uninvestigated dyspepsia and its related factors in an Iranian community. Saudi Med J, 30(3), 397-402. (In Persian)

Batebi S, Masjedi Arani A, Jafari M, Sadeghi A, Saberi M, Davazdah-Emami MH. (2020). A randomized clinical trial of metacognitive therapy and nortriptyline for anxiety, depression, and difficulties in emotion regulation of patients with functional
علائم را شدت مىبخشند و دور باطل قبلى همجنان ادامه مى يابد. نتيجه كيرى

به طور خلاصه نتايج يثوهش نشان داد كه يريشانى روانشناختى و متغيرهاى روانشناختى حوزه درد همجِون تصاوير ذهنى مرتبط با درد، فاجعه آفرينى درد، خودكارآمدى درد و حساسيت احشايى از بيشبينى كنندهاى علائم جسمانى بيمارى سوء هاضمه كاركردى

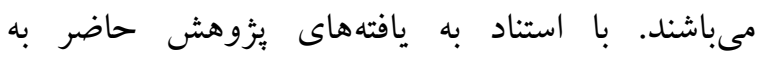
درمانگران و روانشناسان فعال در اين عرصه بيشنهاد مىشود؛ اين عو امل در برنامههاى درمانى بيماران كنجانده شود تا به تبع آن از عود مجدد بيمارى، تشديد علائم و بار بيمارى كاسته شود. اين مطالعه ماند ساير يثوهشها با بال

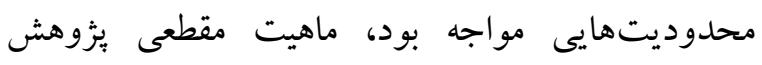

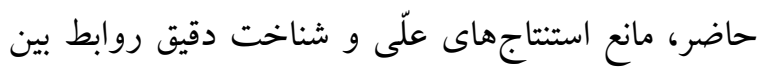
متغيرهاى ئزوهش مى شود. احتمال زيادى وجود دارد كه ترتيب زمانى شكل گيرى متغيرها براساس مدل فرضى ميرى

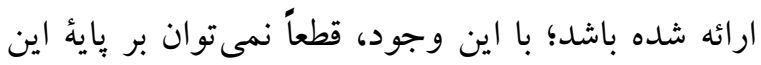

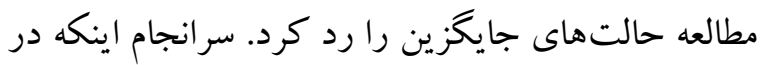
اين مطالعه تنها ابزار جمع آورى اطلاعات برسشنامههايى بود كه جنبه خود كزارشى داشتند؛ بنابراين خالى از سو گيرى نيست جرا كه بِاسخ آزمودنى ها را تحت تأثير مطلوبيت اجتماعى با خطا مواجه مىسازد. استفاده از روشهاى اندازه كيرى متنوع مى تواند به مفهومسازى بهتر متغيرها كمكك كند. همجينين به منظور استنتاج روابط على دقيقتر و شفاف كردن توالى زمانى بين متغيرها، انجام مطالعات طولى بيشنهاد مىشود. 
efficacy modulator on the relationship between alexithymia, pain intensity and paininduced disability in patients with chronic pain

Joumal of Modern Psychology Research. 6(21), 43-60. (In Persian)

Besharat MA. (2008). Preliminary evaluation of psychometric properties of chronic pain selfefficacy questionnaire, research report. University of Tehran. (In Persian)

Bibi A, Lin M, Chi Zhnag X, Margraf J. (2020). Psychometric properties and measurement invariance of Depression, Anxiety and Stress Scales (DASS-21) across cultures. International Journal of Psychology. 55(6), 916-925.

Boyce PM, Talley NJ, Burke C, Koloski NA. (2006). Epidemiology of the functional gastrointestinal disorders diagnosed according to Rome II criteria: An Australian population-based study. IntMed J, 36, 28-36.

Carruthers HR, Miller V, Momis J, Evans R, Tamier N, Whorwell PJ. (2009). Using art to help understand the imagery of irritable bowel syndrome and its response to hypnotherapy. Intl. Joumal of Clinical and Experimental Hypnosis, 57(2), 162-173.

Dworkin RH, Turk DC, Revicki DA, Harding G, Coyne KS, Peirce-Sandner S, et al. (2009). Development and initial validation of an expanded and revised version of the Shortform McGill Pain Questionnaire (SF-MPQ2). Pain, 144(1-2), 35-42.

Esterita T, Dewi SH, Suryatenggara FG, Glenardi G. (2021). Association of Functional Dyspepsia with Depression and Anxiety: A Systematic Review. J Gastrointestin Liver Dis, 30(2), 259266.

Ford AC, Moayyedi P. (2009). Managing dyspepsia. Cument Gastroenterology Reports, 11, 288 294.

Fransen GAJ, Mesters I, Janssen MJR, Knottnerus JA, Muris JWM. (2009). Which patient-related factors determine self-perceived patient adherence to prescribed dyspepsia dyspepsia. Research in Psychotherapy, 23, 157-166. (In Persian)

Besharat MA, Kouchi S, Dehghani M, Farahani H, Moemenzadeh S. (2011). The role of selfmedication? Health Education Research, 24(5), 788-798.

Gosden T, Morris P, Ferreira N, Grady C, Gillanders D. (2014). Mental imagery in chronic pain: Prevalence and characteristics. European joumal of pain, 18(5), 721-728.

Hu N, Wang K, Zhang L, Liu ZJ, Jin Z, Cui RL, Zhang HJ, He ZH, Ke Y, Duan LP. (2021). Epidemiological and clinical features of functional dyspepsia in a region with a high incidence of esophageal cancer in China. Chin Med J, 134(12), 1422-1430.

Jones M, Sharp L, Crowell M. (2005). Psychosocial Comelates of Symptoms in Functional Dyspepsia. Clinical Gastroenterology and Hepatology, 3(6), 521-528.

Junga ZC. (2019). Getting Interested in Functional Gastrointestinal Patients. ACG Case Rep J, 6(5), e00087.

Just N, Alloy LB. (1997). The response styles theory of depression: tests and an extension of the theory. Journal of Abnormal Psychology, 106, 221-229.

Kachooei AR, Ebrahimzadeh MH, Erfani Sayyar R, Salehi M, Salimi E, Razi S. (2015). Short Form-McGill Pain Questionnaire-2 (SFMPQ-2): a cross-cultural adaptation and validation study of the Persian version in patients with knee osteoarthritis. Archives of bone and joint surgery, 3(1), 45. (In Persian)

Karkkola P, Sinikallio S, Flink N, Honkalampi K, Kuittinen M. (2018). Pain self-efficacy moderates the association between pain and somatization in a community sample. Scandinavian Journal of Pain, 19(1), 101-108.

Kirkham JA, Smith JA, Havsteen-Franklin D. (2015). Painting pain: an interpretative phenomenological analysis of representations of living with chronic pain. Health Psychol, 34(4), 398-406.

Koloski N, Jones M, Walker MM, Veysey M, Zala A, Keely S. (2019). Population based study: 
atopy and autoimmune diseases are associated with functional dyspepsia and irritable bowel syndrome, independent of psychological distress. Aliment Pharmacol Ther, 49, 546555.

Koloski NA, Jones M, Walker MM, Keely S, Holtmann G, Talley NJ. (2021). Sleep disturbances in the irritable bowel syndrome and functional dyspepsia are independent of psychological distress: a population-based study of 1322 Australians. Aliment Pharmacol Ther, 54, 627-636.

Koloski NA, Talley NJ, Boyce PM. (2002). Epidemiology and health care seeking in the functional GI disorders: a population-based study. Am J Gastroenterol, 97, 2290-299.

La JH, Sung TS, Kim HJ. (2008). Peripheral corticotropin releasing hormone mediates post-inflammatory visceral hypersensitivity in rats. World J Gastroenterol. 14, 731-736.

Labus JS, Naliboff BD, Berman SM, Suyenobu B, Vianna EP, Tillisch K, Mayer EA. (2009). Brain networks underlying perceptual habituation to repeated aversive visceral stimuli in patients with imitable bowel syndrome. Neuroimage, 47(3), 952-960.

Lee HJ, Lee SY, Kim JH, Sung IK, Park HS, Jin CJ, Chun HJ. (2010). Depressive mood and quality of life in functional gastrointestinal disorders: differences between functional dyspepsia, imitable bowel syndrome and overlap syndrome. General hospital psychiatry, 32(5), 499-502.

Levy RL, Langer SL, Romano JM. (2014). Cognitive mediators of treatment outcomes in pediatric functional abdominal pain. Clin J Pain, 30(12), 1033-1043.

Lin Z, Sarosiek I, Forster J, Damjanov I, Hou Q, McCallum RW. (2010). Association of the status of interstitial cells of Cajal and electrogastrogram parameters, gastric emptying and symptoms in patients with gastroparesis. Neurogastroenterol Motil, 22(1), 56-61.
Lonsdale J. (2010). Imagery and Emotion in Chronic Pain. Unpublished Doctoral Thesis, University of Edinburgh.

Lovibond PF, Lovibond SH. (1995). The structure of negative emotional states: comparison of the Depression Anxiety Stress Scales (DASS) with the Beck Depression and Anxiety Inventories. Behav Res Ther, 33(3), 335-343.

Luo Y, Keefer L. (2021). Role of psychological questionnaires in clinical practice and research within functional gastrointestinal disorders. Neurogastroenterol Motil, 33(12), 1-7.

MacCallum RC, Browne MW, Sugawara HM. (1996). Power analysis and determination of sample size for covariance structure modeling. Psychological methods, 1(2), 130-149.

Mahmoudi F, Maddahi ME, Poursharifi H, Meschi F. (2019). Comparison of the Effectiveness of Acceptance and Commitment Group Therapy and Cognitive-Behavioral Group Therapy on Quality of Life, Anxiety and Depression in Patients with Functional Indigestion. Joumal of Health Promotion Management, 8(4), 43-52. (In Persian)

Mayer EA, Gebhart GF. (1994). Basic and clinical aspects of visceral hyperalgesia. Gastroenterology, 107(1), 271-293.

McGuigan J. (2008). Castrophizing and increasing behavioural activity as mediators of the pain self-efficacy depression relationship in chronic low back pain, Thesis. Seattle, Seattle Pacific University.

Mosher CE, DuHamel KN, Egert J, Smith MY. (2010). Self-efficacy for coping with cancer in a multiethnic sample of breast cancer patients: associations with barriers to pain management and distress. The Clinical journal of pain, 26(3), 227.

Moshiree B, Talley NJ. (2021). Functional dyspepsia: A critical appraisal of the European consensus from a global perspective. Neurogastroenterol Motil, 33(9), 1-9. (In Persian)

Newton E, Schosheim A, Patel S, Chitkara DK, VanTilburg MA. (2019). The role of psychological factors in pediatric functional abdominal pain disorders. 
Neurogastroenterology \& Motility, 31(6), e13538.

Nicholas MK. (2007). The pain self-efficacy questionnaire: taking pain into account. European joumal of pain, 11(2), 153-163.

Nkurunziza A, Dusabejambo V, Everhart K, Bensen S. (2016). Validation of the Kinyarwandaversion Short-Form Leeds Dyspepsia Questionnaire and Short-Form Nepean Dyspepsia Index to assess dyspepsia prevalence and quality-of-life impact in Rwanda. BMJ, 6, e011018.

Overland M. (2014). Dyspepsia. Med Clin North Am, 98(3), 549-64.

Park JH, Kim S, Park JW, Ko SJ, Lee S. (2017). Feasibility study of structured diagnosis methods for functional dyspepsia in Korean medicine clinics. Integr Med Res, 6(4), 44351.

Philips C. (2011). Imagery and pain: The prevalence, characteristics, and potency of imagery associated with pain. Behavioural and Cognitive Psychotherapy, 39(5), 523-540.

Pourtavakoli S, Hajializadeh K, Samavi A. (2018). Validation and Reliability of Visceral sensitivity index. Biannual Joumal of Clinical Psychology \& Personality, 16(2), 239-246. (In Persian)

Power M, Dalgleish T. (2015). Cognition and emotion: From order to disorder. Psychology press, Hove.

Sahan HE, Yildirim EA, Soylu A, Tabakci AS, Cakmak S, Erkoc SN. (2018). Comparison of functional dyspepsia with organic dyspepsia in terms of attachment patterns. Compr Psychiatry, 83, 12-8.

Sahebi A, Asghari MJ, Salari RS. (2005). Validation of depression anxiety and stress scale (DASS-21) for an Iranian population. J Iran Psychol, 1(4), 299-313. (In Persian)

Sajjadian I, Neshat Dost HT, Molavi H, Bagherian Sararoudi R. (2012). Cognitive and emotional factors effective on chronic low back pain in women: Explanation the role of fearavoidance believes, pain catastrophizing and anxiety. J Res Behav Sci, 9(5), 305-316. (In Persian)

Salehi, Sh, Sajjadian I. (2018). The Relation between Self-compassion with Intensy, Catasrophizing, and Self-efficacy of Pain and affect in Women with MusculosKetal Pain. Joumal of Anesthesiology and Pain, 8(2), 72-83. (In Persian)

Sheikh M, Mansourjozan Z, Amini MM. (2020). The Effect of physical Activity and Training of Progressive Muscle Relaxation on the Level of Anxiety and perceived Stress in Patients with Covid-19. Sport Psychology Studies, 9(32), 227-248. (In Persian)

Sullivan MJR, Bishop SR, Pivik J. (1995). The Pain Catastrophizing Scale: Development and validation. Psychological Assessment, 7(4), 524-532.

Suren M, Okan I, Gokbakan AN, Kaya Z, Erkormaz U, Arici S. (2014). Factors associated with the Pain Catastrophizing Scale and validation in a sample of the Turkish population. Turk J Med Sci, 44, 104-108.

Talley N, Haque M, Wyeth J, Stace N, Tytgat G, Stanghellini V, Jones M. (1999). Development of a new dyspepsia impact scale: The Nepean Dyspepsia Index. Alimentary pharmacology \& therapeutics, 13(2), 225-235.

Teasdale TW, Antal A. (2016). Psychological distress and intelligence in young men. Personality and Individual Differences, 99, 336-339.

Turk DC, Gatchel RJ. (2002). Psychological approaches to pain management. Gulford Publication, New York.

Van Oudenhove L, Crowell MD, Drossman DA, Halpert AD, Keefer L, Lackner JM. (2016). Biopsychosocial aspects of functional gastrointestinal disorders. Gastroenterology, 150, 1355-1367.

Vaziri Sh, Lotfi-Kashani F. (2013). Identity Styles and Psychological Distress. Thought and Behavior in Clinical Psychology, 7(26), 77-86. (In Persian) 
Wade BL. (2003). The meaning of chronic pain: a phenomenological analysis, South Africa Jouran of Physiotherapy, 9(1), 196.

Wang Q, Zhao Y, LIU W, Zhang X. (2012). Using Delphi method to develop the health behavior self-efficacy scale for functional dyspepsia patients. Chinese Joumal of Practical Nursing, 28(32), 66-68.

Wertli MM, Burgstaller JM, Held U, Steurer J, Weiser SH. (2014). Response to the Letter to the Editor: Re: Wertli MM, Burgstaller JM, Weiser S, Steurer J, Kofmehl R, Held U. Influence of catastrophizing on treatment outcome in patients with nonspecific low back pain. A systematic review. Spine Publish Ahead of Print, 39, 263-273.

Zargar Y, Dehghanizadeh Z, Mehrabizadeh Honarmand M, Kadkhodaei A. (2012). The effectiveness of stress management cognitive behavior on functional dyspepsia symptoms and quality of life in patients with functional dyspepsia. Govaresh, 17(3), 148-155. (In Persian)

Zvolensky M, Bakhshaie J, Norton PJ, Smits JJ, Buckner JD, Garay L, Manning K. (2017). Visceral sensitivity, anxiety, and smoking among treatment-seeking smokers. Addictive Behaviors, 75, 1-6. 